\title{
The Role of Teachers and Families in Improving Motivation and Learning Outcomes of Students
}

\author{
Firja Ahmad ${ }^{1 *}$ Fatimah Saguni ${ }^{2}$, and Rustina Rustina ${ }^{3}$ \\ ${ }^{1}$ Islamic Education Department, Postgraduate, Institut Agama Islam Negeri Palu \\ ${ }^{2}$ Islamic Education Department, Postgraduate, Institut Agama Islam Negeri Palu \\ ${ }^{3}$ Islamic Education Department, Postgraduate, Institut Agama Islam Negeri Palu
}

\begin{abstract}
This study examines the role of teachers and families in improving motivation and learning outcomes of students. This study uses qualitative methods in the form of field research. The data are collected through observation, interviews and documentation. Data Analysis was performed using data reduction, data presentation and data verification. The results showed that the teachers' roles in increasing students'learning motivation are to clarify goals, arouse students' interests through learning processes, extracurricular activities and selfdevelopment programs and create a pleasant learning atmosphere. The roles of the family are to provide attention and affection, provide guidance and advice as well as supplying students with learning facilities they need. In improving students' learning outcomes, teachers and families need to communicate and cooperate for instance the teacher gives the task and the family carries out supervision at home. However, the lack of family attention caused by economic problems and busyness at work resulted in the insignificance of the families' role in increasing motivation and learning outcomes of students.
\end{abstract}

ARTICLE

INFORMATION

Keywords:

Teacher,

Family,

Role,

Motivation,

Learning, 


\section{Pendahuluan}

Elementary School Teachers as the spearhead of success in shaping a quality generation of the nationapparently need high ability and professional attitudes in order tobe effective in educating their students to be quality. The teachers prove their working performance through the quality of students, both in terms of psychological, mental and spiritual. The formation of the ability and professional attitudes of elementary school teachers is indeed not easy.Having professional abilities does not simultaneously foster professional attitude, because there are many determining factors. Although teachers have been educated in the field of education, this ability and professional attitude are not automatically formed because formal education program does not emphasize their formation. According to Mulyasa, the lack of professionalism among teachers is due to the absence of teaching patterns transformationfrom conventional systems to competency systems, excessive workload, and less teachers conducting classroom action research. On this basis, teachers' competency standards and certification are regulated so that teachers become professional and have appropriate competencies in teaching. Therefore, it is formally stated in The Teachers and Lecturers Law No. 14 / 2005 that besides having an undergraduate degree as a prerequisite, professional teachers must possess four basic competencies.

The efforts of government to improve teacher professionalism through setting teachers' competency standards and certification must also be supported by the willingness of teachers to improve their quality and professionalism so that national education goals can be achieved. As stated in the Teacher and Lecturer Law thatteacher is a professional educator with the main task of educating, teaching, guiding, directing, training, assessing and evaluating students in the formal education.

The principal task of headmaster is to foster and develop the school he leads so that education and teaching become more effective and efficient. It can only be implemented properly if active cooperation with all school teachers is fostered. In order to performhis role and function as an education manager, the headmaster must have the right strategy to empower teachers through cooperation, provide encouragement and motivation thensupervise their performance to improve professionalism as teachers.

Teacher professionalism is a must in realizing knowledge-based school. It is an understanding of learning, curriculum, and the development of human styles including learning styles. The headmaster is 
responsible for providing the best service to teachers, staff, students, and other parties involved in the school. To provide the best service, he compiles data and information based school programs about the school he leads, guiding groups of teachers, counselors, laboratory assistants, librarians, administrative staff, and other education staff in the school. In accordance with his authority, the headmaster is responsible to provide, maintain school facilities and infrastructure, build cooperative relations between schools and the community and empower the community's potential for school development. As a supervisor, he controls the performance of the teaching staff. Supervision and control are appropriate measures to prevent education staff from making deviations and being more careful in carrying out their work.

The implementation of their professional abilities requires teachers to be able to increase their roles, as informants, organizers, motivators, directors, initiators, transmitters, facilitators, mediators, and evaluators so that their competencies are developed.

However, the implementation in the real world does not run as they should. Both teachers and families are not actively supportingeducation. For this reason, researchers want to examine how teachers and parents perform their role in supporting student learning.

\section{Literature Review}

2.1 Previous Literature

The teacher professionalism improvement through supervision at Petimbe Small Elementary School (SDN), Palolo District Sigi has never been discussed by researchers beforehand. Therefore it attracts the researchers to discuss it in a scientific study. Some previous researches related to this research are:

Dadan Wahidin, The Importance of Educational Supervision as an Effort to Increase Teachers Professionalism which was conducted at MAN 3 Malang. This researchfound that the implementation of regular and continuous supervision has implications in the learning quality improvement. ${ }^{1}$

Irfan, The Effect of Classroom Visits Supervision by the Headmaster and School Climate on the Teachers' Performance in four state junior high schools in SubMKKSTaman, in Pemalang Regency. The result of this research is that the supervision of classroom visits by theheadmasteras well

\footnotetext{
${ }^{1}$ Dadan Wahidin, Pentingnya Supervisi Pendidikan Sebagai Upaya Peningkatan Profesionalisme Guru. Studi di MAN 3 Malang, http://dadan.blogspot.com/2009/06/pentingnyasupervisi-pendidikan.html, Tesis, Tidak diterbitkan, 2009.
} 
asschool climate have a positive effect on teachers' performances. ${ }^{2}$

M. Ashari in his research Academic Supervision of Tsanawiyah Supervisors in Jepara found that the implementation of procedures and stages of academic supervision has been performed accordingto the theory and regulations set by the government.Furthermore, he found that the headmaster experienced psychological constraints inconducting academic supervision to teachers as his colleague, and the deputy head curriculum had not optimally run his role in academic development,especially in improving the quality of learning process. The research also revealed thatthere is a disproportion between the supervisors' workload ratio and the availability of Tsanawiyah Supervisors in Jepara. $^{3}$

Siti Najjmiatul Ulum Rinnike, The Relationship between the Intensity of Principal Academic Supervision and Teachers' Motivation at SMPN 106 Jakarta. This research found that the implementation of the principal academic supervision at

${ }^{2}$ Irfan. Pengaruh Pelaksanaan Supervisi Kunjungan Kelas Oleh Kepala Sekolah Dan Iklim Sekolah Terhadap Kinerja Guru Di Empat SMP Negeri Sub MKKS Taman Kabupaten Pemalang, Semarang

: Tesis UNNES Semarang, Tidak Diterbitkan, 2007.

${ }^{3}$ M. Ashari, Supervisi Akademik Pengawas Sekolah Tsanawiyah Di Kabupaten Jepara, Tesis, Tidak diterbitkan, 2011.
SMPN 106 Jakarta had a significant influence on the teacher's work motivation. The intensity had an effect of $50,13 \%$ on teachers' work motivation, while $49.87 \%$ was influenced by other factors. ${ }^{4}$

Unlike the researchers above, this research takes an educational institution in Petimbe Kecil State Elementary School (SDN) located on Trans Palu, Napu Road, Petimbe Village, Palolo Subdistrict, Sigi Regency, as the research subject.This study discusses how the supervision is carried out at Petimbe KecilState Elementary School (SDN) andit's implications and how to improve teacher professionalism in the target school.

\subsection{Teacher Professionalism}

Etymologically, profession means work. In Good's Dictionary of Education quoted by Mujtahid, profession is defined as "a job that requires relatively long preparation of specialization in Higher Education and is controlled by a special code of ethics". ${ }^{5}$ In The Great Dictionary of the Indonesian Language, profession is defined as "a field of work which based on a specific

\footnotetext{
${ }^{4}$ Siti Najjmiatul Ulum Rinnike, Hubungan Insensitas Pelaksanaan Supervisi AkademikKepala Sekolah Dengan Motivasi Kerja Guru di SMPN 106 Jakarta. Tesis UIN Syarif Hidayatullah, Jakarta: Tidak di Terbitkan, 2010.

5 Mujtahid, Pengembangan Profesi Guru, (Malang: UIN-Maliki Press, 2011), 20.
} 
education of expertise (such as skills, vocation, etc.)" 6

Profession is a position or job. ${ }^{7}$ professionalism means professional character. Professional people have different attitudes with the unprofessional even in the same job or say in one workspace. ${ }^{8}$

In this sense, it can be emphasized that the profession is a job which requires certain expertise, skills and specialization. Theoretically, a profession cannot be done by just anyone who was not previously trained or prepared for that profession.

Martinis Yamin believes the profession means "someone who pursue a job based on expertise, abilities, techniques and procedures based on intellectuality". ${ }^{9}$ Profesi adalah suatu lapangan pekerjaan yang dalam melakukan tugasnya memerlukan teknik dan prosedur ilmiah, memiliki dedikasi serta cara menyikapi lapangan pekerjaan yang berorientasi pada pelayanan yang ahli.Profession is a field of work that requires scientific techniques and procedures, and are oriented to expert service.

6 Pusat Bahasa Departemen Pendidikan Nasional, Kamus Besar Bahasa Indonesia, (Jakarta: Balai Pustaka, 2001), Edisi III, 897.

${ }^{7}$ Moh. Uzer Usman, Menjadi Guru Profesional (Bandung: Remaja Rosdakarya, 1999), 15.

${ }^{8}$ Sudarman Danim, Inovasi Pendidikan (Bandung: CV. Pustaka Setia, 2002), 23.

${ }^{9}$ Yamin Martinis, Profesionalisasi Guru dan Implementasi KTSP, (Jakarta: Gaung Persada Press, 2007), 3.
Lexically, the word profession contains the following meanings: (1) profession shows and expresses a belief (to profess means to trust), belief (to belief in) in truth (religious teaching) or a person's credibility. (2) profession can show and express a certain job or business. ${ }^{10}$

In subsequent developments, the word profession gets a clearer or more stringent meaning. There are two provisions regarding the use of the word profession. First, an activity can only be said as a profession if the activity is carried out for a living.Secondly, it is determined as a profession if that an activity to make a living is done with a high level of expertise. ${ }^{11}$

The occurrence of associations that bind people who devote themselves to a position together, further instructions regarding behavior that must be obeyed by each member of the profession are arranged.First, that each profession is developed to provide certain services to the community both individually and collectively. Secondly, it is determined that the profession is not just a livelihood or field of work. In the word 'profession' also includes the notion of devotion to something,

\footnotetext{
10 MudlofirAli, Pendidik Profesional; Konsep, Strategi, dan Aplikasinya dalam PeningkatanMutu Pendidikan di Indonesia, (Jakarta: Rajawali Pers, 2012), 2.

11 Abuddin Nata, Manajemen Pendidikan; Mengatasi Kelemahan Pendidikan Islam di Indonesia,(Jakarta: Kencana, 2010), 153.
} 
for example justice, truth, relieving human suffering, and so on. Third, every field of profession has an obligation to improve work procedures that underlie its continuing service. $^{12}$

A profession is a job, it can also manifest as a position within a bureaucratic hierarchy, which demands certain expertise and has special ethics for the position and standard service to the community.

The essence of profession is that someone must have certain expertise. In simple society, the expertise is obtained by imitating and passed on from parents to children or from community groups to future generations. In modern society, the expertise is obtained through special education and training. As opposed to a profession is an amateur. A profession is an activity for someone to live his life (earning a living). An amateur pursue an activity mainly because of a hobby/looking for fun, to fill his spare time. $^{13}$

In general, a teacher as an educator holds very significant roles including as a corrector, inspiration, informant, organizer, motivator, initiator, facilitator, advisor,

\footnotetext{
${ }^{12}$ Ibid, 154-155.

13 Tilaar H.A.R ,Membenahi Pendidikan Nasional, (Jakarta: PT Rineka Cipta, 2009), 86.
}

demonstrator, classroom manager, mediator, supervisor, and evaluator. ${ }^{14}$

Specifically, some of the teachers' roles in face-to-face learning were suggested by Moon, quoted by Hamzah B. Uno, as follows:

1) The teacher as the designer of learning

2) Teachers as managers of learning

3) The teacher as a learning director

4) The teacher as an evaluator

5) The teacher as a counselor

6) Teachers as curriculum implementers. ${ }^{15}$

Every profession absolutely has a code of ethics, including teacher. According to Sonny Keraf, quoted by Rugaiyah and Atiek Sismiati, the code of ethics is a "moral code that applies specifically to professionals in the field." 16

Teachers as professionals need to have a code of ethics for teachers and make it a guideline that regulates the work of teachers during service. The teacher's code of ethics is a provision that binds all attitudes and actions of the teacher. It is one of the characteristics that must exist in the teaching profession itself. The following is a description of the Indonesian teacher's code

\footnotetext{
${ }^{14}$ Djamaroh Syaiful Bahri, Guru dan Anak Didik dalam Interaksi Edukatif; Suatu PendekatanTeoritis Psikologis, 43-48.

15 Hamzah B. Uno, Profesi Kependidikan; Problema, Solusi, dan Reformasi Pendidikan diIndonesia, (Jakarta: Bumi Aksara, 2011), 22- 25.

${ }^{16}$ Rugaiyah Atiek Sismiati, Profesi Kependidikan, (Bogor: Ghalia Indonesia, 2011), 1213.
} 
of ethics as a result of the formulation of the XIII PGRI congress on November 21-25, 1973 in Jakarta.: ${ }^{17}$

\section{Methodology}

The researchers employed qualitative approach with one of the schools in Palu as the object of research, in this case Petimbe Kecil State Elementary School (SDN), Palolo District, Sigi Regency.

Data were collected using observation techniques, in-depth interviews and studies from shared written documents. While the data analysis was done using reduction and verification techniques with various data sources. The reduced data were then analyzed referring to the theoretical concepts used in this study

\section{Result and Discussion}

\subsection{The Role of Teachers in Improving}

\section{Learning Motivation}

The teacher in every learning activity needs to clarify the learning objectives because the targets to be achieved in learning are determined based on them. In addition, clarifying the objectives can also increase students' learning motivation, that is, students understand why the learning is necessary.

\footnotetext{
17 Amiruddin Hatibe, Cara Sukses Pendidikan dan Latihan Profesi Guru (PLPG), (Yogyakarta: SUKA-Press UIN Sunan Kalijaga, 2012), 12.
}

Clarifying the objectives of learning in the classroom is explained by Nur Jannah:

In the learning process, before I start the lesson, I usually do activities before learning including praying, attendance checking, and doing apperception. I also do not forget to give some kind of advice and motivation, such as why we have to go to school, study and help parents at home. This is in accordance with what I have compiled in the RPP.. ${ }^{18}$

The results of the interview revealed that the teachers motivate students through an explanation of why school is essential, why they had to study and help parents. With these advices, students will remember more about what they have done at home and at school related to their duties as students.

Apperception activity before starting the lesson is very important. Besides repeating the core of the previous lesson, it also serves as an explanation to the connection between the subject matter that was taught beforehand and the subject matter to be learned.

The existence of the apperception at least provides information to students about the indicators that will be achieved in learning and the linkage of the previous subject matter to the present.

\section{Generating Learner's Interest}

\footnotetext{
${ }^{18}$ Nurjannah, dalam 'Wawancara' di Ruang Guru Pada Tanggal 07 Juni 2017 pukul 08.37 WITA
} 
Motivation and interest are very closely related and always associated each other. Generating students' interests can be done in two ways, developing interest through learning activities and through extracurricular activities, coaching programs or other talent development programmed by the school.

Generating the interest of students in learning activities can be done by giving rewards or prizes. Zulkiflin explained:

Rewards or prizes are given to students to overcome their boredom in learning, so that they remain enthusiastic in learning. Especially during the last lesson, students are usually less eager to follow the lesson.. ${ }^{19}$

Boredom in learning most often occurs in the last class hours, when students have exerted their concentration to study in the first and second class. Boredom that comes is usually influenced by drowsiness or fatigue when studying for hours.

Based on the researchers' observation, indeed when entering the last subject, students' interest in the subject is no longer the same as the first and second class. The students become less enthusiastic when listening to the teacher's explanation, come in and out of the classroom during class time, some even skip the class.

${ }^{19}$ Zulkiflin, dalam 'Wawancara' di Ruang Guru Pada Tanggal 17Juni 2017 pukul 10.15 WITA
To overcome this boredom and arouse students' interest in following the subject, the teacher needs to give a reward. However, it needs the teacher's creativity to see the right time to give the gift or reward, because if the gift is given continuously then students will get used to learning to get rewards, not from the basic needs of the students to develop themselves.

The forms of reward are explained by Zulkiflin, as follows:

Giving gifts or rewards can be in the form of grades, praises, gifts or freed from additional duties. For me, the thing that I do most often in giving rewards is to ask the other students to give applause if a student expressesopinion or give extra grade to those who answer questions correctly.If all students get 100, I praise the first one who gets it. ${ }^{20}$

The results of the interview revealed that giving rewards in the form of praises and extra grades should be managed well. Praising the students can be done directly or indirectly such as asking other students to give applausewhen a student answers questions or expresses their opinions. Extra grades are presented not only to those who answer questions correctly, but also to those who show their effort inanswering questions or trying to express their opinions.

${ }^{20}$ Zulkiflin, dalam 'Wawancara' di Ruang Guru Pada Tanggal 17 Juni 2017 pukul 10.15 WITA 
Generating the interest of students can also be done through extracurricular activities or other coaching activities. This was as explained by the Head of MTs Nida'ul Khairaat Pombewe Kec. Biromaru Kab. Sigi, Zakiah:

The type of extracurricular activities in this school is Scouting. The other programs are religious coaching which is carried out every morning before the lessons begin, Friday morning dhikr and self-development programs. $^{21}$

The existence of scouting as an extracurricular activity can increase students' learning motivation due to new knowledge about scouting in each of their activities. Besides, it greatly motivates students through many kinds of games played.

Students are also motivated by the religious activities habituation program, where they are jointly guided to read and write the Qur'an. This is as stated by Nurjanah:

Religious activities habituation program in the form of reading and writing the Qur'an are carried out every morning before the lesson begins. Students are guided in each class, each class has a teacher assigned to guide students who read the written Qur'an and also memorize short surahs. ${ }^{22}$

${ }^{21}$ Zakiah, dalam 'Wawancara' di Ruang Kepala Sekolah Pada Tanggal 5 Juni 2017 pukul 09.00 WITA

${ }^{22}$ Nurjannah, dalam 'Wawancara' di Ruang Guru Pada Tanggal 07 Juni 2017 pukul 08.37 WITA
According to the researchers, the model of religious habituation carried out in each class such as when receiving lessons, is quite effective for students who are mostly not fluent in reading the Qur'an. They are motivated because they are guided together with other classmates instead of individually.

\section{Creating a Fun Learning Atmosphere}

Creating a fun learning atmosphere is vital for teachers. An unpleasant learning atmosphere will lead to boredombecausebasically someone will do something when it is fun or the results obtained is pleasure.

Regarding the fun learning atmosphere, Mohammad Masrukin said:

The teachers should provide material that will not make students feel bored. The teacher must always control the learning progress of students and use a variety of learning methods in order to to create a fun learning atmosphere. ${ }^{23}$

Boredom is a sign of unpleasant learning atmosphere. To prevent this, the teacher should provide fun subject matter. In addition to elaborating the subject matter in pleasant ways, teachers also need to use varied learning methods.

\footnotetext{
${ }^{23}$ Mohamad Masrukin, dalam 'Wawancara' di Ruang Guru Pada Tanggal 14 Agustus 2017 pukul 11.20 WITA
} 
Regarding the learning methods applied in teaching in the classroom, Nurjannah explained:

I always use a variety of methods in teaching, in addition to the lecturingmethod, I often divide the class into some groups to do discussions. ${ }^{24}$

The results of the interview revealed that using a variety of learning methods will ease the students to understand the lessons. With or without teaching aids, theory or practice, essentially, with a variety of learning methods will make the students motivated in learning.

Another Problem existed in MTs. Nida'ul Khairaat Pombewe Kec. Biromaru Kab. Sigi is that the teacher cannot use electronic learning media such as laptops and infocus. That was caused by the lack of access to electricity.

\subsection{The Role of Teachers in Improving} Learning Outcomes

Giving assignments is a way for teachers to get the students learn independently. Through this activities, students are expected to find answers to the questions and improve problem solving skill. Sualni states:

Teachers must always communicate with students, give tasks to do at

\footnotetext{
${ }^{24}$ Nurjannah, S.Pd.I, dalam 'Wawancara' di Ruang Guru Pada Tanggal 07 Juni 2017 pukul 08.37 WITA
}

school and at home so that students feel given responsibility by the teacher. It can also be material for parents to oversee students' learning at home.. ${ }^{25}$

The results of the interview show that students are given the task so that students feel given responsibility by the teacher. This is in line with what was expressed by Nurjannah:

I always give assignments related to lessons and additional assignments so that students feel given a responsibility. However some students are just being indifferent. ${ }^{26}$

The results of the interview show that not all students do the assignments. Even though teachers at school assign responsibility in the form of tasks to do at home, when no supervision from the families, then the efforts to improve learning outcomes will not produce satisfying results.

Assessment and evaluation conducted by teachers in schools aims to get information on the students' learning outcomes. The written assessment is done by providing questions in the worksheets then do scoring based on the students' answers. While the attitude assessment is done by observing the students' actions and behavior when attending the lesson.

\footnotetext{
${ }^{25}$ Sualni, dalam 'Wawancara' di Ruang Guru Pada Tanggal 27 Agustus 2017 pukul 09.45 WITA

${ }^{26}$ Nurjannah, dalam 'Wawancara' di Ruang Guru Pada Tanggal 27 Agustus 2017 pukul 09.45 WITA
} 
In addition to assessing written test and attitude, teachers must also provide motivation and encouragement to students. Zulkiflin explained:

Teachers must be more extra in assessing students, not only in the written and attitude assessment, but also are expected to provide support for students, this is done in order to improve students' learning outcomes. I for example, in addition to assessing students' knowledge and attitudes, I also encourage them on how to get good grades. $^{27}$

The motivation or encouragement given by the teacher will stimulate the students to achieve satisfactory learning outcomes.

\subsection{The Role of Families in Increasing Learning Motivation}

\section{a. Giving Attention and Affection}

As children, students need family attention which is a basic instinct for every human being. The amount of attention, will affect the personality of students. Families that give more attention will have a good effect on students, conversely the lack of family attention will have a negative impact on the development of students. It will have a devastating effect on their learning motivation, Zakiah explains:

${ }^{27}$ Zulkiflin, dalam 'Wawancara' di Ruang Guru Pada Tanggal 27 Agustus 2017 pukul 09.45 WITA
Parents become less attentive to students, they are no longer able to provide encouragement to students. This can get worse if the environment where they live is less comfortable. They can be easily affected by a bad social environment. ${ }^{28}$

The lack of attention and affection to children because of work causes the familyunable toprovide encouragement in the form of guidance and advice in learning.Eventually, students are affected by a bad social environment.

To investigate how family attention and affection towards students, the researchers interviewed three students who are considered problematic in class namely Agus, Ikfal and Ajis Wahid. The attention of the families of students as stated by Agus, one of the students of Class VIII MTs. Nida'ul Khairaat Pombewe Kec. Biromaru Kab. Sigi:

My parents, work as farmers. In the morning they go to the rice fields until evening, while I go to school. Coming home from school, I eat, then go out to play or sometimes take a nap. My parents will just come home in the evening.Sometimes I also help them in the fields. ${ }^{29}$

The result of the interview illustrates the lack of time spent between families and

${ }^{28}$ Zakiah, dalam 'Wawancara' di Ruang Kepala Sekolah Pada Tanggal 05 Juni 2017 pukul 09.00

${ }^{29}$ Agus, dalam 'Wawancara' di Ruang Kelas Pada Tanggal 27 Agustus 2017 pukul 09.15 WITA 
students. This condition provides chances for students to go anywhere or do anything without family supervision.

The demands of work force parents to spend most of their time at work. Very little time are provided to chat with children so their opportunity to share with family about their good grades or problems is very limited.

Another student named Ikfal expressed the attention and affection of his parents as follows:

My parents are farmers, they go to the garden early in the morning, I always take care of my younger siblings, so I rarely go to school. At home, I usually do homework, but I don't have the time to study because I have to look after my younger siblings and do the housekeeping. ${ }^{30}$

The results of the interview above revealed that the lack of family attention to the student named Ikfal is due to the demands of their work.

\section{1. b. Giving Guidance and Advice}

One of family obligation is to provide guidance and advice to students. With these, students are expected to be able to control and guard themselves from the negative impact of social environment.

Several families expressed that, in practice, guidance and advice can only be

\footnotetext{
${ }^{30}$ Ikfal, dalam 'Wawancara' di Ruang Kelas Pada Tanggal 27 Agustus 2017 pukul 09.15 WITA
}

performed if communication between the family and students is established properly, means there is an open and close relationship between the family and children.

However, there is afamily understanding in which the researchers disagree. It is the family give up all the responsibilities to the school teachers to guide students. As revealed by Sadia, one of the families of students in Class VIII MTs Nida'ul Khairaat Pombewe Kec. Biromaru Kab. Sigi:

Our hope as parentsis that we send our children to a good school so that they can become employees, have a salary, unlike us his parents who are dying to fight in the garden to earn a living. I sent my child to school at his school (MTs Nida'ul Khairaat Pombewe, Biromaru District, Sigi Regency) so that he could be a smart child, especially hisIslamic knowledge. ${ }^{31}$

The interview indicatesthat the family expectationof enrolling students in MTs Nida'ul Khairaat are: First, for students to gain knowledge as a guarantee to get a promising job in the future, such as becoming a civil servant. Second, for students to have sufficient Islamic knowledge and morality, considering MTs Nida'ul Khairaatis an Islamic school.

Regarding the full submission of guidance from family to school, it can be

\footnotetext{
${ }^{31}$ Sadia, dalam 'Wawancara' di Rumahnya Pada Tanggal 28 Agustus 2017 pukul 16.18 WITA
} 
identified from the results of an interview with Sri Munayati, one of the students' families:

I am very thankful that I sent my child to Islamic school. Now, he already know how to do salat and recite the Quran. It was really hard to told him to do salat, he was usually angry if I did. but at school, he was afraid of his teacher, so I was very grateful. ${ }^{32}$

The results of the interview revealed that the family fully expects the school in this case the teacher to guide the studentsbecause students are more afraid or reluctant to the teacher compared to his own family. It can be seen from the statement of gratitude for the Islamic knowledge her child has now, in this case salat and reciting the Qur'an.

\section{c. Fulfilling Learning Facilities}

One of the family roles in increasing students' learning motivation is to fulfill their learning facilities. Even though it is not the main determining factor in increasing the motivation of students.Fulfillingchildren's learning facilities is a form of family expectation that students learn seriously.

Fulfillment of learning facilities can also be said as a sacrifice of the family for the success of students. Among the families of the students whom the researchers met,

\footnotetext{
${ }^{32}$ Sri Munayati, dalam 'Wawancara' di Rumahnya Pada Tanggal 28 Agustus 2017 pukul 20.18 WITA
}

Ridwan, one of the parents of students of class VIII MTs. Nida'ul Khairaat said:

I often advise my child and always fulfill his requests hoping that he will obey and listen to my advice to stay in school. I buy booksb and toys, basically I do all kinds of ways and try my best so that my child stays in school. ${ }^{33}$

The results of the interview show that the family do their effort by fulfilling their needs and wants, from books to toys to maintain the students' motivation in learning.

However, not all families can fulfill the learning facilities of students because of the economic factors. One of eighth grade students' family of MTs Nida'ul Khairaat Pombewe who provided a comment on this matter was Harun. He stated:

It was very difficult to buy textbooks for my child, because it is expensive. I have not even bought him new school clothes. He still wears the clothes from last year. Actually I really want to buy new clothes, shoes and books for my child, but I can't afford it. ${ }^{34}$

The results of the interview revealed that the main problem in fulfilling the students' learning facilities are economic factors. Their monthly income is low but the price of the facilities is very expensive.

\footnotetext{
${ }^{33}$ Ridwan, dalam 'Wawancara' di Rumahnya Pada Tanggal 27 Agustus 2017 pukul 20.18 WITA

${ }^{34}$ Harun, dalam 'Wawancara' di Rumahnya Pada Tanggal 26 Agustus 2017 pukul 09.00 WITA
} 
Finally, the families find it difficult to fulfill the students' learning needs.

\subsection{The Role of Families in Improving Learning Outcomes}

Learning outcomes are a measure of changes in students' behavior after going through the learning process. Teachers and families play an important role to teach and guide students both at school and at home in improving students' learning outcomes.

Each student has a different personality, cheerful, reflective, peevish, quiet and so on. By understanding the personality of students, the teacher and family will be able to understand how to deal with these students, how to communicate with them and so on.It is essential to be recognized because their personality is inseparable from the influence of the environment in which students live. Ani Setiawati explained:

The teacher really deserves to know and must know the personality of the students (at MTs Nida'ul Khairaat), both at school and in the family environment. Because the nature and behavior of students as well as family backgrounds vary from one another, there is a need for collaboration between the teacher and the family. ${ }^{35}$

The interview result above revealed that MTs Nida'ul Khairaat students have different personalities due to the background

\footnotetext{
${ }^{35}$ Ani Setiawati, dalam 'Wawancara' di Ruang Guru Pada Tanggal 29 Agustus 2017 pukul 09.00 WITA
}

of the environment in which they live. In class VIII, students have different family backgrounds in both economy and occupation, this of course also has implications for students' personalities.

Therefore, the teachers' job is to know and understand that personality. But further there has to be collaboration between the teacher and the family, at least conducting communication. Through it the teacher can understand that in certain families based on the environment, will produce students who have certain personalities as well.

However, students' learning outcomes at MTs. Nida'ul Khairaat Pombewe do not depend on the economic and occupational background of students' families. There are students who are economically disadvantaged but their learning outcomes are satisfactory and some others get low result.

On the contrary,there are those who have high learning outcomes because their family is in the category of economically capable, but there are also some who do not get satisfactory grade. As stated by Nurjannah, the homeroom teacher of class VIII:

The economic background of students in this class are diverse, some from well-off families, some from underprivileged ones. There are those who are economically disadvantaged but have good grades such as students 
named Nurfadilah and Moh. Rizal. They got good grades in every subject. Other students who also had good grades were Retma Anjar Swansi and Rahmadian. The rest is mediocre. There are also some students which considered problematic, they are Agus, Ikfal and Ajis Wahid. ${ }^{36}$

The results of the interview above shows that the students of class VIII MTs Nida'ul Khairaat Pombewe come from diverse economic backgrounds. As mentioned in the results of the interview that there are students who come from well-off families but the learning outcomes are not satisfactory. On the other hand, those who come from disadvantaged families got satisfying learning outcomes, even become high-achieving students.

\section{Conclusions}

Based on the results of the research described earlier it can be concluded that:

The roles of the teacher in increasing students' motivation in MTs. Nida'ul Khairaat Pombewe is at first clarifying the learning objectives. After that, stimulating the interest of students through a fun learning process, and arising students' interest through extracurricular activities and self-development programs. The roles of the teacher in this case has been quite maximal with the efforts made by the teacher.

\footnotetext{
${ }^{36}$ Nurjannah, dalam 'Wawancara' di Ruang Guru Pada Tanggal 07 Juni 2017 pukul 09.00 WITA
}

The roles of the teachers in improving learning outcomes are giving assignments to students both at school and at home as a form of responsibility given by the teacher, and doing evaluation.

The roles of the family in increasing students' learning motivation in MTs. Nida'ul Khairaat Pombewe are giving attention and affection, providing guidance and advice, as well as fulfilling students' learning facilities. But the constraints are the family's economic factors and working demand making their roles becomes very minimal in increasing students' learning motivation.

The roles of the family in improving students' learning outcomes in MTs. Nida'ul Khairaat Pombewe are identifying students 'personalities, and collaborating with teachers to get satisfying learning outcomes.

\section{References}

Ahmadi, Abu Psikologi Umum, Jakarta: Rineka Cipta, 1998

Arianto, Miftahcul Rizqi, Tesis "Pengaruh Lingkungan Keluarga, Lingkungan sekolah, dan Motivasi Belajar Terhadap Perilaku Belajar Siswa Jurusan Administrasi Perkantoran di SMK Masehi PSAK Ambarawa" Program Pascasarjana Universitas Negeri Semarang, 2012

Arifin, Zaenal Evaluasi Instruksional Prinsip-Teknik-Prosedur, Bandung: Remaja Rosdakarya 1990

Arikunto, Suharsimi Prosedur Penelitian Suatu Pendekatan Praktik, Jakarta : PT. Rineka Cipta, 2006

Bangun, Darwin, Hubungan Persepsi Siswa Tentang Perhatian Orang Tua, 
Kelengkapan Fasilitas Belajar, dan Penggunaan Waktu Belajar di Rumah dengan Prestasi Belajar Ekonomi. Jurnal Ekonomi dan Pendidikan. 5 (1): 74-94, 2008

Basya, Hassan Syamsi Mendidik Anak Zaman Kita, Jakarta: zaman, 2001

Daryanto, Evaluasi Pendidikan, (Jakarta: PT.Rineka Cipta, 2005

Departemen Pendidikan Nasional, Kamus Besar Bahasa Indonesia, Jakarta: Balai Pustaka, 2002

Djamara, Syaiful Bahri \& Aswan Zain, Strategi Belajar Mengajar, Cetakan Ketiga. Jakarta: PT.Rineka Cipta, 2006 Muhammad Taqi Falsafi, Anak Antara Kekuatan Gen dan Pendidikan Terj. Ahsin Muhammad (Bogor: Cahaya, 2002

Garawiyan, Banu, Memahami Gejolak Emosi Anak,Bogor: Cahaya, 2002

Hamalik, Oemar Psikologi Belajar dan Mengajar, Bandung: Sinar Baru Bandung, 1992

Handoko, Martin Motivasi Daya Penggerak Tingkah Laku, Jakarta: PT Rineka Cipta, 1992

Hawadi, Reni Akbar Psikologi Perkembangan Anak: Mengenal Sifat, Bakat, dan Kemampuan anak. Jakarta: Grasindo, 2001

Hurlock, Elizabeth B. Psikologi Perkembangan Alih Bahasa oleh Istiwidyanti dan Soedjarwo Jakarta: Erlangga, 2004

Idris, Zahara dkk, Pengantar Pendidikan,Jakarta: Gramedia Widiasarana Indonesia, 1992

Juwariyah, Pendidikan Anak dalam AlQuran, Yogyakarta: Teras, 2010

Kartadinata, Sunaryo Bimbingan di Sekolah Dasar,Jakarta: Direktorat Jenderal Pendidikan Tinggi, 1999

Kartono, Kartini Psikologi Anak, Bandung: Alumni, 1979

Mahmud, dkk. Pendidikan Agama Islam dalam Keluarga,Jakarta: @kademia, 2013
Maslow, Abraham HAL. Motivasi dan Kepribadian 1 Alih Bahasa oleh Nurul Iman Bandung: Remaja Rosdakarya, 1993

Najati, M. Ustman,Belajar $E Q$ \& $S Q$ dari Sunnah Nabi, Bandung: Hikmah, 2002

Nugroho, Aditya, Tesis "Pengaruh Motivasi dan Minat Terhadap Prestasi Siswa pada Mata Diklat Keselamatan dan Kesehatan Kerja Di SMK Negeri 1 Sedayu” Program Pascasarjana Universitas Negeri Yogyakarta, 2013

Nuryanti, Lusi Psikologi Anak, Jakarta: PT Indeks, 2008

Poerwadarminto, Kamus Umum Bahasa Indonesia, Solo: PT.Tiga Serangkai Pustaka Mandiri, 2003

Purwanto, Ngalim Psikologi Pendidikan,Bandung: PT Remaja Rosdakarya, 2003

Qaimi, Ali, Menggapai Langit Masa Depan Anak, Bogor: Cahaya, 2002

Rahmah, Firstyana Ulya, Tesis "Pengaruh Kreatifitas Guru Motivasi Belajar Siswa terhadap Hasil Belajar Siswa SMA Negeri 13 Semarang” Program Pascasarjana Universitas Negeri Semarang, 2011

Rahardjo, Mudja,Quo Vadis Pendidikan Islam, Malang: Aditya Media, 2006

Rohman, Arif, Memahami Pendidikan dan Ilmu Pendidikan, Yogyakarta: Laksbang Mediatama Yogyakarta, 2009

Sabir, Khairiyah Husain Taha, Peran Ibu dalam Mendidik Generasi MuslimJakarta: Firdaus, 2001

Sadulloh, Uyoh dkk. PEDAGOGIK (Ilmu Mendidik),Bandung: Alfabeta, 2010

Safaria, Interpersonal Intellegence: Metode Pengembangan

Kecerdasan Interpersonal anak, Yogyakarta: Amara Books, 2005

Sardiman AM., Interaksi dan Motifasi Belajar Mengajar,Jakarta: PT Raja Grafindo Persada, 2005

Satiadarma, Monty, Persepsi Orang Tua Membentuk Perilaku Anak:Dampak 
Pygmalion di dalam Keluarga, Jakarta: Pustaka Populer Obor, 2001

Shapiro, Jerold Lee The Good Father: Kiat Menjadi Ayah Teladan, Bandung: Kaifa, 2003

Siagian, Sondang P., Teori Motivasi dan Aplikasinya,Jakarta: PT Rineka Cipta, 2004

Siahaan, Henry,Peranan Ibu Bapak Mendidik Anak, Bandung: Angkasa, 1986

Slameto, Belajar dan Faktor-Faktor Yang Mempengaruhinya, Edisi Revisi. Jakarta: Rineka Cipta, 2013

Sugihartono dkk.,Psikologi Pendidikan, Yogyakarta: Uny Press, 2007

Sukmadinata, Nana Syaodih Landasan Psikologi Proses Pendidikan,
Bandung: PT Remaja Rosdakarya, 2003

Tafsir, Ahmad, Metodologi Pengajaran Agama Islam, Bandung: Remaja Rosda Karya, 1999

Walgito, Bimo Pengantar Psikologi Umum, Yogyakarta: Yayasan Penerbitan Fakultas Psikologi UGM, 1986

Yusuf, Syamsul Psikologi Perkembangan Anak Remaja, Bandung: Remaja Rosda Karya, 2011 